\title{
Law and Economics in Common-Law, Civil-Law, and Developing Nations'
}

\section{Direito e Economia na Common-Law, Civil-Law e países em desenvolvimento}

\author{
Richard A. Posner ${ }^{2}$ \\ University of Chicago Law School, Chicago, U.S.A. \\ Ipalamk@law.uchicago.edu
}

\begin{abstract}
The law and economics movement is the principal interdisciplinary field of legal studies. This paper traces the history of the movement and explains its basic principles, contrasts the version of the movement that predominates in the United States with the version that prevails in Europe. It is observed the greater emphasis of the former on substantive doctrine and of the latter is focused on rule of law considerations, and emphasizes the importance of the movement for legal and economic reform in developing nations.
\end{abstract}

Key words: law, economy, legal and economic reforms.

\begin{abstract}
Resumo
O movimento do direito e economia é o principal campo interdisciplinar dos estudos jurídicos. Este artigo faz um levantamento histórico do movimento e explica seus princípios básicos, contrastando a versão do movimento que predomina nos Estados Unidos com a versão que prevalece na Europa. Observa-se, assim, maior ênfase da primeira na doutrina substantiva, e a segunda foca os aspectos de estado de direito, enfatizando a importância do movimento para reformas jurídicas e econômicas nas nações em desenvolvimento.
\end{abstract}

Palavras-chave: direito, economia, reformas jurídicas e econômicas.

\footnotetext{
'This is the revised draft of a plenary lecture given at the XXIWorld Congress of the Internationale Vereinigung furr Rechts- und Sozialphilosophie (IVR) in Lund, Sweden, on August 14, 2003. I thank the participants in the Congress for comments that have helped me in revising my lecture for publication.

${ }_{2}^{2}$ Judge, U.S. Court of Appeals for the Seventh Circuit; Senior Lecturer, University of Chicago Law School LBQ 6I I, IIII E. 60th St., Chicago, IL 60637, U.S.A.
} 
Rapid increases in recent decades in the scope and rigor of microeconomics have fostered the emergence and stimulated the continuing growth of a distinct and important subfield of legal theory economic analysis of law, or as it is more commonly (if somewhat misleadingly) called, "law and economics". Each of the leading U.S. law schools has one or more $\mathrm{PhD}$ economists on its faculty, and, in addition, professors in the regular law courses will often include the economic perspective in their course. Nine journals (eight American, one European) specialize in the economic analysis of $\mathrm{law}^{3}$. There are several textbooks, a large monographic literature, two multivolume encyclopedias (both edited by Europeans), and professional associations in the United States, Europe, Latin America, Australia, and Canada. Several federal appellate judges in the United States, including one of the Supreme Court Justices, are former law and economics scholars (Stephen Breyer is the Justice, and among the federal court of appeals judges are Guido Calabresi, Frank Easterbrook, Douglas Ginsburg, Stephen Williams, Ralph Winter, and myself); and most federal, and many state, judges have attended continuing education programs in economic analysis of law.

Anthony Kronman, the dean of the Yale Law School, a critic of the law and economics movement, nevertheless calls it "an enormous enlivening force in American legal thought", and says that it "continues and remains the single most influential jurisprudential school in this country".

Despite Professor Kronman's reference to "American thought" and "this country" (i.e., the United States), the law and economics movement is genuinely international, and has as much relevance to civil law and developing countries as it does to the Anglo-American common law countries. Indeed, there is a distinctive "civilian" law and economics movement that focuses on rule of law issues that are of particular importance to developing countries.

Economic analysis of law has heuristic, descriptive, and normative aspects (for a fuller discussion, see Posner, 2003a). As a heuristic, it seeks to display underlying unities in legal doctrines and institutions; in its descriptive mode, it seeks to identify the economic logic and effects of doctrines and institutions and the economic causes of legal change; and in its normative aspect it advises judges and other policymakers on the most efficient methods of regulating conduct through law. The range of its subject matter has become wide, indeed all-encompassing. Exploiting advances in the economics of nonmarket behavior, economic analysis of law has expanded far beyond its original focus on antitrust, taxation, public utility regulation, corporate finance, and other areas of explicitly economic regulation; while, within that domain, it has expanded to include such fields as property and contract law, pension law, secured transactions and bankruptcy law, and, notably, intellectual property law, a field of especially rapid growth and economic significance. The "new" economic analysis of law embraces such nonmarket, or quasi-nonmarket, fields of law as tort law, family law, criminal law, free speech, procedure and evidence, legislation, public international law, the law of privacy, the rules governing the trial and appellate process, environmental law, the administrative process, the regulation of health and safety, the laws forbidding discrimination in employment, and social norms viewed as a source of, an obstacle to, and a substitute for formal law. It also includes the study of the principal legal institutions, including judge and jury, regulatory agencies, and legislatures. Economists are extensively employed as expert witnesses in such fields as antitrust and securities regulation, as well as in every type of case - personal-injury cases as well as commercial cases - in which damages have to be calculated or other forms of legal remedy applied.

Although economic analysis of law has had its biggest practical impact in fields of explicitly economic regulation, such as antitrust and public utility regulation, where economic analysts have played a significant role in orienting American law in a free-market direction, increasingly its mark is felt in other areas of law as well, such as environmental law, where tradable emissions rights are a hallmark of the economic approach to the environment, the law of eminent domain, where the increasing judicial concern with "regulatory" takings bears the stamp of the economic analysts of law, and divorce law, where feminist and economic insights have joined to emphasize the economic dimension of household production, resulting in the adoption

\footnotetext{
3 Journal of Legal Studies, Journal of Law and Economics, Journal of Law, Economics, and Organization, American Law and Economics Review, International Review of Law and Economics, Supreme Court Economic Review, Research in Law and Economics, Commentaries on Law and Economics, and European Journal of Law and Economics; and next year the European Association for Law and Economics plans to launch its own journal. In addition, many articles applying economic analysis of law appear in the standard law reviews and economics journals.

${ }^{4}$ Remarks of Kronman (1995) at the Second Driker Forum for Excellence in the Law.
} 
by courts of new methods for dividing property and calculating alimony in divorce cases. The recent financial scandals in the United States, however, are bound to refocus economic analysis of law on one of its core concerns, the problem of "agency costs" in the corporate domain, that is, the problem of aligning the incentives of corporate managers with those of the corporation's diffuse owners, the shareholders, who may have little incentive or information for monitoring the behavior of their (nominal) agents, the managers.

The most ambitious theoretical aspect of the economic approach to law has been the proposal of a unified economic theory of law. In that theory (comprehensively expounded in Posner, 2003a), law's function is understood to be to facilitate the operation of free markets and, in areas where the costs of market transactions are prohibitive, to "mimic the market" by decreeing the outcome that the market could be expected to produce if market transactions were feasible. A corollary of this proposition is the positive economic theory of the common law, the theory that the Anglo-American common Law (that is, judge-made as distinct from legislated law, encompassing such important fields as property, contract, trust, and tort law, as well as basic criminal, procedural, and remedial law) is best understood as if the judges in fashioning that law had been consciously trying (which they were not) to bring about an efficient allocation of resources.

The positive theory builds on Ronald Coase's famous article, from the early 1960s, on social cost (Coase, 1960). The "Coase Theorem" holds that where market transaction costs are zero, the law's initial assignment of rights is irrelevant to efficiency, since if the assignment is inefficient the parties will rectify it by a corrective transaction. There are two important corollaries. The first is that the law, to the extent concerned with promoting economic efficiency, should strive to minimize transaction costs, for example by clearly defining property rights, by making them readily transferable, and by creating cheap and effective remedies for breach of contract. Economic analysts of law have identified a number of doctrines, procedures, and institutions for achieving the aim of minimizing market transaction costs. Immediately, however, a question arises concerning comparative law and economics. When doctrines are found to differ across countries, should the difference be ascribed to relevant economic differences or to the fact that some countries do not have efficient legal doctrines? Consider for example the fact that the standard remedy for breaching of contract in AngloAmerican law is damaged, with specific performance (i.e., an order, injunctive in nature, commanding the contract breaker to perform his obligations under the contract) available only when damages are inadequate, and Continental law, where specific performance is a routine rather than exceptional remedy for breaching of contract ${ }^{5}$. Are the Anglo-American rule efficient and the Continental inefficient, or vice versa? Perhaps both are efficient, given different economic conditions. To the extent that - for reasons that may be unrelated to differences in legal institutions - the United States has a more dynamic economy than that of Continental Europe, in the sense of more rapidly adaptive to changed conditions and new opportunities, there is greater need to allow adjustment of contractual relations when conditions change from what they were when a contract was made. A remedial system that emphasizes damages makes it easier for either party to "walk away" from the contract, because he cannot be forced by a court to perform his contractual duties, though he must compensate the other party for the consequences of the breach. In contrast, when specific performance is a standard remedy for breaching of contract, a party cannot walk away from the contract without first negotiating a settlement with the other party that will induce the latter to forget his remedy of specific performance, and the need for such a negotiation will make it harder to abandon the contract, and, at the least, introduce delay.

The second corollary of the economic approach to law that I am expounding is that where, despite the law's best efforts, market transaction costs remain high, the law should simulate the market's allocation of resources by assigning property rights to the highestvalued users. An example is the fair-use doctrine of U.S. copyright law, which among other things allows writers to publish short quotations from a copyrighted work without negotiating with the copyright holder (I 7 U.S.C. sec. 107; Landes and Posner, 2003, chap. 4). The costs of such negotiations would usually be prohibitive; and when they were not prohibitive the usual result of the negotiation thus enabled would be to permit the quotation at a price very close to zero, and so the doctrine of fair use brings about the result that the market would bring about if market transactions were feasible.

${ }^{5}$ This actually exaggerates the difference in practice between the two regimes of contract remedy; but there is some difference. 
Coase's (1960) article, important as it is, was not the beginning of economic analysis of law. That economics has a relation to law had been known at least since Hobbes's discussion of property in the seventeenth century. Both David Hume and Adam Smith discussed the economic functions of law.

Jeremy Bentham's contribution was fundamental, both in extending economic thinking to nonmarket behavior and in applying the extension to the criminal law. On the European Continent, Max Weber made important contributions to understanding law's economic role. By the 1930s a handful of legal fields, mainly antitrust and public utility regulation, that dealt explicitly with competition and monopoly were receiving the sustained attention of leading English and American economists. And by 1968, when Gary Becker published an article on the economics of crime and punishment (Becker, 1968), reviving and refining Bentham, it began to seem that, perhaps, no field of law could not be placed under the lens of economics with illuminating results. The decades since have vindicated that expectation. Lately the range and depth of the economic approach to law have been enlarged by developments in game theory, signaling theory, and the economics of nonrational behavior ("behavioral economics"). As I have emphasized, it is not merely an ivory-towered enterprise. In the United States it has influenced, in addition to the examples I gave earlier, the calculation of damages in personal injury suits, the regulation of the securities markets, the content of federal sentencing guidelines, and the law governing investment by pension funds and other trustees. The deregulation movement and the increased respectability of free-market ideology generally, owe something, and perhaps a great deal, to the law and economics movement.

Non-economists tend to associate economics with money, capitalism, selfishness, a reductive, unrealistic conception of human motivation and behavior, a formidable mathematical apparatus, and a penchant for cynical, pessimistic, and conservative conclusions. It earned the sobriquet of "the dismal science" because of Thomas Malthus's thesis that famine, war, and sexual abstinence were the only ways in which population and food supply could be equilibrated. The essence of economics is none of these things, however.The essence is extremely simple, although the simplicity is deceptive.

The simple can be subtle, can be counterintuitive; its antithesis is "complicated," not "difficult". Most economic analysis consists of tracing out the consequences of assuming that people are more or less rational in their social interactions, which means little more than that people prefer more to less, in other words picking efficient means to their ends (instrumental rationality), whatever those may be. In the case of the activities that interest the law, these people may be criminals or prosecutors or parties to accidents or taxpayers or tax collectors or striking workers - or even law students. Students treat grades as prices, so that unless the university administration intervenes, unpopular professors, in order to keep up their enrollments, will sometimes compensate students for the low perceived value of the course by giving them higher grades, that is, by raising the price that the professor pays for the student (or, equivalently and perhaps more intuitively, reducing the cost to the student of enrolling in the professor's course). This very simple analysis of incentives is helpful in explaining the well-known phenomenon of "grade inflation", the tendency of average grades to drift upward - even though students are not becoming smarter or working harder. Grade inflation has coincided in the United States with the decline in the proportion of required courses. The more courses are elective rather than required, the greater is the competition among professors for students, and so the more frequent is the awarding of high grades as a way of attracting or retaining students, imparting an upward thrust to grade-point averages.

I said that the economist's tracing out of the consequences of a practice or policy is subtle as well as simple, and here is an example. The "spendthrift trust", a very common form of trust in the United States, withholds from the trustee authority to pay out any of the money or other property in the trust to the creditors of the trust's beneficiaries. The law will enforce such a restriction, yet it has seemed to many students of the law a fraud on creditors for the trust beneficiary, assuming that his whole wealth is in the spendthrift trust, can borrow all he wants, spend what he borrows, and not be coercible by law to repay the lenders. But economics suggests the opposite conclusion - that, provided the provision preventing creditors from reaching into the trust is not concealed, a spendthrift trust limits borrowing by the trust beneficiary, because he can't offer security to the lender; he, thus can't make a credible commitment to repay. From here it is but a step to see how increasing the rights of debtors in bankruptcy, far from causing an avalanche of reckless borrowing, could reduce the amount of borrowing, and so the incidence of bankruptcy, by causing lenders to make smaller loans to risky borrowers. So lenders may oppose easy bankruptcy not because they fear that there will be more defaults, but because they fear a reduction in 
the volume of loans. Imagine how few loans there would be if borrowers had no obligation to repay. Notice also how creditors are as badly hurt by excessively stringent as by excessively lenient bankruptcy rules. If creditors had the legal right, as under ancient Roman law, to carve up a defaulting borrower into as many pieces as there were creditors, the default rate on loans would be very low but most people would be afraid to borrow it.

Rationality implies decision-making, and people often have to make decisions under conditions of profound uncertainty. Consider the question how much care a rational person should take to avoid an accident. The accident will occur with probability $P$ and impose a cost (call it "L," for loss), while eliminating the possibility of such an accident would impose a cost on the potential injurer, a cost that I shall call $B$ (for burden). The cost of avoiding the accident will be less than the expected accident cost (or benefit of avoiding the accident) if $B$ is smaller than $L$ discounted (multiplied) by $P$; that is, Law and Economics 7I. B < PL. In that event, should the potential injurer fail to take the precaution (perhaps because he does not reckon the cost to the accident victim a cost to him) and should the accident occur as a result of that failure, he is properly regarded as being at fault and is made to pay the victim's damages so that other potential injurers in his position will be given an incentive to take cost-justified precautions. $B<P L$ is the negligence formula announced by the noted federal appellate judge Learned Hand in a judicial opinion in 1947 but not recognized as an economic formula for negligence until many years later. The formula is simple, but its elaboration and its application to specific doctrines in the law of torts have generated an immense and illuminating literature. Hand was not an economist, and he proposed the formula to decide a legal case.This is an example of the isomorphism of legal doctrines and economic principles; the latter can often be used to illuminate and refine the former. That isomorphism is a key to the fruitfulness of positive economics of law, that is, to understanding the law as a system for economic optimization.

I have been discussing accidental injuries, but the Hand formula can accommodate deliberate ones as well, simply by putting a minus sign in front of $B$. That models the case in which, rather than having to expend resources in order to avoid an injury (positive $B$ ), the injurer expends resources on inflicting the injury, so that he would actually save resources by not injuring (negative $B$ ). Since PL, being a positive number, must always be greater than a negative $B$, it is apparent that deliberate as distinct from accidental injuries should be presumptively unlawful. It is a mite less obvious that deliberate injuries cannot be left entirely to the tort system to deter. The person who expends resources in order to inflict an injury is likely to anticipate a substantial gain, whether pecuniary or nonpecuniary, from succeeding; he is also likely to take measures to avoid detection. On both counts, the optimal sanction for a deliberate injury is likely to be higher than that for an accidental injury. For example, if the prospective injurer anticipates a net gain of $G$, and a probability of being punished of $P<1$, the sanction must be fixed at $S=G / P$ to equal his expected benefit of injuring and, thus, make inflicting the injury worthless to him. Many deliberate injurers cannot pay the optimal sanction, and so society has to resort to nonpecuniary sanctions in an effort to impose on the injurer a disutility equal to or greater than the expected utility to him of the injury. Moreover, many deliberate injurers have no assets - this may be why they turned to crime to support themselves - and so the victims of deliberate injuries will often lack an incentive to bring a tort suit. On both counts, then, society needs to have criminal law to back up tort law. This analysis helps to explain the extraordinary severity of penalties for illegal trafficking in drugs, a crime the social costs of which probably are low. That is immaterial, once a decision is made to criminalize and thus try to deter the conduct. Because the sale of drugs is a potentially lucrative business (high $G$ ), and, more important, because as a "victimless" crime the difficulty of apprehension is acute (low $P$ ), the optimal sanction is high.

Let me turn to a less familiar use of economic analysis than explaining the economic rationality of rules and practices: simplifying legal analysis by breaking down doctrinal boundaries. We already glimpsed this in relating criminal to tort law, assigning the former a supplementing role. And notice how decision under uncertainty played a decisive role in both analyses. The uncertainty of the criminal's being caught, like the uncertainty of a careless act's leading to injury, is a critical determinant of the optimal sanction.

Dr. Miles Medical Co. v. John D. Park \& Sons Co. involved the legality under antitrust law of a contract by which a supplier of patent medicines forbade his dealers to charge a price for his medicines lower than his suggested retail price; this is the practice known as resale price maintenance. The Supreme Court held the practice illegal, pointing out that it had the same effect as would an agreement among the dealers to fix the price at which they would sell Dr. Miles's medicines - that is, the same effect as a dealers' cartel, which would be a per se violation of antitrust law. But there was another 
effect, which the Court overlooked. Dealers who are unable to compete in price yet would make money if they could sell more will compete in non-price dimensions of competition instead, such as stocking more inventory or having better-informed salespeople, in order to attract more customers, since every additional sale will generate a profit equal to the difference between the resale price fixed by the supplier and the cost to the dealer of the additional sale. If dealer-provided services are important to the manufacturer's marketing strategy, he can use resale price maintenance to evoke them. For by setting the minimum resale price above the dealer's barebones cost of sale, the manufacturer will be giving dealers an incentive to compete with one another for additional sales by offering customers more service. This competition will transform the profit built into the minimum resale price into enhanced point-of-sale services - which is what the manufacturer wants.

A dealers' cartel would have this effect too; members of the cartel, each of whom would like to increase his sales at the cartel price because that price is by definition above cost, would try to lure customers from other dealers by offering better service. The difference is that in the cartel case the dealer may be providing more service than the customer wants; the customer might prefer a lower price with less service. If that is indeed what the customer prefers, the supplier will not engage in resale price maintenance, for if he did he would lose business and profits to a competitor who did not engage in the practice. My next example may seem unrelated. Critics of the deregulation of the airline industry have pointed out that airline service is in some respects inferior to what it was in the days when it was a regulated industry. Planes are more crowded, there is less legroom, the food is poorer ${ }^{6}$. Gone, for example, are the piano bars from American Airlines' Boeing 747s. This is what economics predicted. The regulated airline industry was a government enforced cartel. Prices were kept high and as a result competition was deflected into non-price competition. When the airlines had finally competed away all their cartel profits in the form of service competition, the industry was ripe for deregulation. And when it was finally deregulated, price fell and with it the level of service, because this combination was what the consuming public wanted, as we can infer from the enormous growth in air travel since deregulation.

So we see - and this is the point of the discussion - that resale price maintenance of patent medicines and the deregulation of airline transportation raise the same economic issue, that of the relation between price and non-price competition, even though one involves goods and the other services, one is old and the other is recent, and one involves the judicial interpretation of the antitrust laws while the other legislative reform of common carrier regulation. This is a recurrent experience in the economic analysis of law. Practices, institutions, bodies of law that are wholly unrelated when viewed through the lens of orthodox legal analysis are seen to involve the identical economic issue. Whole fields of law are interchangeable when viewed through the lens of economics. When I was a law student, the law seemed a collection of completely unrelated rules, procedures, and institutions. Economics reveals a deep structure of law that has considerable coherence. This is extremely important both to law teaching and, as in my example of the differences in Anglo-American and Continental contract remedies, to the study of comparative law.

I have been discussing American law and the American law and economics movement, though much of what I have said is equally applicable to civil law systems. Though I mentioned a doctrinal difference, the number and size of those differences, among nations at comparable levels of economic and political development, are, I believe, generally modest. The institutional differences, however, are profound, having mainly to do with the different structures of the judicial career in Anglo-American (especially U.S.) versus Continental, and most other, legal systems. I will come back to that point; but first I want to explain what I said at the outset was the distinctively civilian "take" on law and economics. It begins with Aristotle, who in the Nicomachean Ethics set forth a theory of law that he called "corrective justice". The essential point that Aristotle made is that if someone through wrongful behavior (the wrongdoer) disturbs the preexisting balance between himself and another person to the injury of the latter (the victim), some form of redress must be provided that will, to the feasible extent, restore that preexisting balance - that will correct, in other words, the departure from equilibrium that was brought about by the wrongful act.

Aristotle derived from his theory of corrective justice a corollary of critical importance to the evolution of legal theory. The corollary is that corrective justice abstracts from the personal qualities, the merit or ${ }^{6}$ These developments were well advanced before the terrorist attacks on the United States of September II, 200I, resulted in increased costs of and reduced demand
for airline service, spurring further cuts in quality. 
desert, of the wrongdoer and his victim. The victim may be a bad man and the wrongdoer a good one, having in mind the character and entire course of a person's career, the summation of all his good and bad deeds, and not just the particular episode that resulted in the injury to the victim. Nevertheless, the victim is entitled to redress. The reason this is a corollary of corrective justice rather than a separate principle of justice is that corrective justice seeks to redress a preexisting equilibrium rather than to change it. The court doesn't use the occasion to enrich or impoverish wrongdoer or victim on the basis of a judgment about their merits or deserts apart from the circumstances of the injury itself, for that would be not to restore the parties to the preexisting equilibrium but to create a new equilibrium.

This process of correction remains a cornerstone of law in all civilized societies. The reason is practical (Aristotle was a practical thinker). If obtaining redress for injuries depended on a person's reputation, people would invest inordinate resources in becoming well liked, well regarded. To the extent such investments took the form of doing genuinely good things, they would enhance social welfare. But often it would be much easier to obtain a good reputation by cultivating the friendship of the powerful, allying with the powerful through marriage, avoiding unpopular stands, and other methods unrelated, indeed detrimental, to the good of society. Furthermore, even when a person obtained a good reputation by good means, once he had that reputation and could use it to inflict wrongful injuries with impunity on persons who did not have a good reputation, incentives to wrongful behavior would be created. The friendless would be an outlaw class on whom any of the "good" could prey with impunity. Energies would be deflected from socially constructive activities into rent seeking and clientelism. The state would be weakened.

So we want law to be "impersonal" in rather a literal sense. We want the judges to abstract from the personal characteristics of the parties to the litigation before them and treat them as representatives of classes of activity, such as drivers and pedestrians. This aspiration for legal justice received canonical expression (in the civilian tradition) in Max Weber's concept of formal rationality. Law engaged Weber's interest as both an illustration of and as a causal agent in the process of modernization (more broadly, of social evolution), a process that is at the heart of Weberian sociology. Modernization is for Weber the process by which instrumental rationality, implemented through such institutions and practices as bureaucracy, professionalism, and specialization, comes to supplant older methods of social ordering. The older methods include family and clan ties, magic, charisma, intimidation, and other means of social control in which nonrational associations and influences predominate. Law, in Weber's analysis, participates in this modernizing process by shucking off its supernatural, charismatic, and discretionary elements and becoming increasingly cut-and-dried, rational, and bureaucratic - increasingly a system in which disinterested civil servants, constituting a professionalized judiciary, resolve disputes by applying clearly stated rules designed to promote rational economic planning by private and public actors to facts that these civil servants also ascertain rationally. The rules do not prescribe any private actions - do not tell people what contracts to make, what risks to take, what callings to follow. Instead they create the framework within which people can go about their business acquiring and exploiting property, making contracts, investing and lending, engaging in risky activities, and so forth, confident that known, clear, substantively neutral rules provide the exclusive statement of their public rights and duties. To the extent that the legal system conforms to these criteria, it attains formal rationality the optimal environment for capitalism.

Judges are not to be the cheerleaders for capitalism, however. They are to enforce the abstract norms of the law without regard to the consequences for the persons and activities encountered in the cases that they are called upon to decide. This neutrality, neutrality not only as to personal worth as in Aristotle's concept of corrective justice, but as to ideology as well, is important not only for enhancing the predictability of law - and it is predictability, above all, that Weber thought capitalists require of the legal framework but also for reassuring the potentially restive classes in society that the law is not infected by class bias.

The legal system that Weber had in mind as exemplary for modernization was the civil-law system found in Germany and other Continental nations. Yet the earliest capitalist superpower, namely Great Britain, and the most advanced capitalist power of his day as of ours, namely the United States, were common law rather than code countries. The embarrassment that the common law poses for Weber's thesis is only slight, however. The Continental judiciary is (and was in Weber's time as well) more creative and less rule-bound, less "bureaucratic," than Weber believed, while the common law has always been more predictable than outsiders realize; and so in short the common law and civilian legal traditions are convergent. What capitalism essentially requires of law is the protection of property rights, and enforcement 
of freedom of contract, by reasonably disinterested judges, rather than the maximum clarity and coherence attainable by legal rules.

The content of legal rules is as important as their form, moreover, and the common law rules fashioned by English and American judges may have contained precepts more supportive of economic efficiency than the counterpart rules in civilian countries. The reason may be that English and American judges are generally appointed from the practice of law and are, thus, more worldly than their counterparts in the career judiciaries of the civilian legal systems.

Friedrich Hayek carried Weber's emphasis on formal rationality to the point of denying that judges should utilize economics in their decisions (Posner, 2003b, chap. 7). Hayek argued for this position in part because of his great respect for custom ("spontaneous order," in his lexicon), which he thought would provide more efficient rules than anything a public official, including a judge, could devise, but partly also because of a Weberian distrust of judicial discretion. For reasons that I cannot go into here but have discussed at length elsewhere (see Posner, 2003b, chap. 7), Hayek goes too far in promoting custom as a source of law, neglecting the fact that inefficient customs are inevitable given the process by which customs are formed and the difficulty (because of the decentralized character of custom formation) of changing them to keep abreast of social and economic change, a problem that is more acute the more dynamic the society. And hence Hayek's prescription is especially inapt for the United States.

The emphasis that what I am calling the civilian law and economics movement places on broad ruleof-law values rather than on detailed doctrines and procedures of the sort I discussed earlier in this paper has particular relevance for developing countries; a brief amplification of this point will bring the paper to a close.

When law is weak, the enforcement of property and contract rights frequently depends on the threat and sometimes the actuality of violence, on family alliances that may be dysfunctional in the conditions of a modern economy, and on cumbersome methods of self-protection. These substitutes also create a bias against new firms, which do not have a reputation that they can use to persuade potential contracting partners of their reliability, and a bias in favor of simple, simultaneous exchanges over more complex transactions, since the more nearly simultaneous the performance of the parties to a contract is, the less need there is for a legal remedy against nonperformance.

A poor country may not be able to afford a good legal system, but without a good legal system it may never become rich enough to afford such a system. It can be argued, therefore, that since it is much more costly and time-consuming to create efficient legal institutions than to enact efficient rules for the existing inefficient institutions to administer, the focus of reform should be on the latter (see Hay et al., 1996). The creation and dissemination of a rule involve small fixed costs and (like other information goods) negligible marginal costs, while legal institutions require heavy inputs of high-priced, educated labor. This implies that the rules-first strategy is better the more populous a country is, because the cost of creating a rule is invariant to the number of people the rule will apply to, though this advice must be tempered by recognition that the more populous a country, the more heterogeneous it is likely to be, which may require a corresponding variety of rules. However this may be, China, the world's most populous country, has followed the rules-first strategy, introducing modern, commercially oriented rules of law at the same time that it liberalized the economy.

The relative simplicity of rules as compared to standards has two consequences for the kind of weak judiciary common in a developing country.Applying rules places fewer demands on the time and the competence of the judges and is, therefore, both cheaper and more likely to be accurate. Rules also facilitate the monitoring of judges, and so reduce the likelihood of bribery and the influence of politics in the judicial process. The less discretion a judge has in making decisions, the easier it will be for observers to determine whether he has decided a case contrary to law or is systematically favoring one class or group of litigants over another. This is of course the sort of consideration that greatly influenced Weber and Hayek.

Other economic measures for reducing judicial corruption and incompetence include:

(i) Backloading judicial compensation by creating generous pension rights that are forfeited if the judge is removed from office for incompetence or venality. Even if the likelihood that his misbehavior will be detected is slight, if the cost to him if it is detected is very great, he may be deterred because the expected cost (the cost if he is detected multiplied by the probability of detection) may be great (see Becker and Stigler, 1974).

(ii) Having judges sit in panels rather than by themselves or having them sit with juries. In either case, both the transaction costs of bribery, and the likelihood that if he accepts bribes this will be discovered, will rise.

(iii) Reducing penalties in order to reduce the gain from bribing judges and other officials not to impose 
them. If the fine for speeding were $\$ 1,000$, the incentive of a police officer to demand and of the speeder to pay a bribe to avoid a ticket would be great.

(iv) Prioritizing. If the greatest danger to a developing nation's prosperity is the threat that government will confiscate people's property, then it may make sense to establish a special court whose sole mission is to check the government (the French approach - the Conseil d'État is that court). The judges of this court will have to be competent, ethical, and well-paid, but since the court's jurisdiction will be so circumscribed, the aggregate resources of both human and physical capital required to equip the court will be modest. And if the court is confined to purely economic issues, the political authorities may be willing to tolerate its independence, especially if they understand how much such an institution can do for the nation's prosperity.

As the examples I have given throughout this paper illustrate, the basic job of the economist is to remind people, notably including lawyers and judges, of the consequences that non-economists tend to overlook, consequences that often though not always are adverse or at least costly, of actual or proposed policies and practices. This use of economics ought to be welcomed by lawyers who think it is important to discover what the actual consequences of legal doctrines and institutions are, even those doctrines and institutions that have achieved sacred-cow status within the legal profession, and by judges who must cope with a wide range of cases, not only commercial ones, that present economic issues. It ought to be welcomed by law professors as well who seek to advance the understanding of the legal system, to stimulate their students, and to create a theoretical framework for grasping the underlying unity, and social utility, of the law.

\section{References}

BECKER, G.S. 1968. Crime and punishment: An economic approach. Journal of Political Economy, 76:169-217.

BECKER, G.S.; STIGLER, G.J. 1974. Law enforcement, malfeasement, and compensation of enforcers. Journal of Legal Studies, 3: I- 18.

COASE, R.H. 1960. The problem of social cost. Journal of Law and Economics, 3: I-44.

HAY, J.R.; SHLEIFER, A.;VISHNY, R.W. 1996. Privatization in transition economies: toward a theory of legal reform. European Economic Review, 40:559-567.

KRONMAN,A.T. 1995. The second driker forum for excellence in the law. Wayne Law Review, 42:I I5-6I0.

LANDES,W.M.; POSNER, R.A. 2003. The economic structure of intellectual property law. Cambridge, Harvard University Press, $442 \mathrm{p}$.

POSNER, R.A. 2003a. Economic analysis of law. $6^{\text {th }}$ ed., New York, Aspen, $747 \mathrm{p}$.

POSNER, R.A. 2003b. Law, pragmatism, and democracy. Cambridge, Harvard University Press, $398 \mathrm{p}$. 